\title{
Analisis faktor-faktor yang mempengaruhi konsumen memilih akomodasi pada situs tiket.com di wilayah kuta selatan
}

\author{
T C Oktapiani Putri ${ }^{1}$, Agus Muriawan Putra ${ }^{2}$, Agung Sri Sulistyawati ${ }^{3}$ \\ Diploma IV Pariwisata Fakultas Pariwisata, Universitas Udayana \\ Jl. Dr. R. Goris No. 7 Denpasar \\ Email: doracikita@yahoo.com ${ }^{1}$
}

\begin{abstract}
Abstrak
Sektor perjalanan merupakan salah satu produk atau layanan yang banyak diakses melalui internet saat ini seiring dengan meningkatnya keperluan mobilitas antar daerah seperti wisata dan pekerjaan. Oleh karena itu, semakin banyak bermunculan perusahaan startup di di Indonesia yang bergerak di ra nah pemesanan tiket pesawat dan akomodasi perhotelan. PT. Global Tiket Network ata u biasa y ang dikenal sebagai Tiket.com yang merupakan salah satu perusahaan online travel agency yang menyediakan pelayanan reservasi hotel, tiket pesawat dan kereta api secara online. Tujuan dari pen elitia n ini ada lah untuk mengetahui faktor-faktory ang mempenga ruhi konsumen memilih a komodasi serta mengetahui faktor yang dominan berkontribu si da lam mempengaruhi konsumen memilih akomodasi pa da situs Tiket.com di wila yah Kuta Selatan. Metode pengumpulan data dilakukan dengan teknik ku esioner, dokumentasi, dan studi kepustakaan. Teknik pengambilan sampel menggunakan rumus Coch ran dengan tingkat kesalahan sampel(sampling eror) $10 \%$, sa mpel yang dia mbil seb anyak 96,04 responden dan dibula tkan menjadi 100 responden dan menggunakan analisis fak tor konfirmatori.

Hasil penelitian inimenjelaskan terdapat lima faktor terb entuk y ang mempen ga ruhi konsumen memilih akomodasipada situs Tiket.com di wilayahKuta Selatan yaitu kemudahan dan system informasi $(45,978 \%)$, daya tarik visual situs $(7,196 \%)$, pelayanan konsumen $(6,117 \%)$, citra perusahaan $(4,530 \%)$, dan motivasi pembelian $(4,057 \%)$. Ada pun faktor ya ng mendominasi a dalah faktorkemudahan dan sistem informasi situs yang terdiri da ri 13 variabel, yakni: (1) kemudahan pada sa at mencari situs web, (2) waktu yang dihabiskan untuk mengakses web, (3) nama domain perusaha an yang digunakan, (4) kemudahan pada saat melakukan pemesanan, (5) informasi y a ng lengkap, (6) informasi yang akurat, (7) informasi yang disajikan menarik, (8) pemaparan informasi yang tepat, (9) ketersediaan dan aksesibilitas, (10) harga yang kompetitif, (11) pengalaman secara keselu ruhan, (12) kea manan data pribadi, serta (13) kea manan saat melakukan pembayaran.
\end{abstract}

Kata kunci : Memilih Akomodasi, Online TravelAgent

\begin{abstract}
The tra vel sector is one of the products or services that a re widely accessed through the internet today which are provided for inter-regional mobilities such as tourism and work trip. Therefore, more companies are emerging startups in Indonesia that are en gaged in the field of a irline ticket booking and hospitality accommodation. PT. The Global Ticket Network or commonly called Tiket.com is on e of the on line travel agent companies that provides hotel reservation services, airplane tickets and trains online. The purpose of this research is to to find out the factors that influence consumers to make decisions to choose accommodation and the dominant factors that contribute to influencing con sumers to make decisions on Tiket.com sites in the South Kuta. The method of data collection is done by questionnaire, documentation, and library study. The sampling technique uses the Cochran formula with a sample error rate (sampling error) of 10\%, the sample taken is 96.04 respondents and rounded up to 100 responden ts and uses confirmatory factor analy sis.

The results of this study explain that there are five factors that influence consumers to make a decision to choose accommodation on Tiket.com sites in the South Kuta are a and named as follow: convenience and information systems (45.978\%), site visual appeal (7.196\%), customer service $(6.117 \%)$, company image $(4,530 \%)$, and purchase motivation $(4,057 \%)$. The dominating factors are convenience factors and the site information sy stem which consists of 13 variables: (1) convenience when searching for a website, (2) time spent accessing the web, (3) company domain name used, (4 )ease when ordering, (5) complete information, (6) accurate information, (7) information presented is interesting, (8) ex posure to appropriate information, (9) availability and accessibility, (10) competitive
\end{abstract}


prices , (11) overall ex perience, (12) security of personal data, and (13) security when making payments.

Keywords: Decision to Choose Accommodation, OnlineTravel Agent

\section{PENDAHULUAN}

Salah satu fenomena yang terjadi dan sangat dirasakan dalam perkembangan penggunaan internet yaitu berubahnya aktivitas jual-beli barang dan jasa dari pembelian secara langsung di tokotoko konvensional, kini mulai beralih pada pembelian secara online. E-commerce merupakan perdagangan elektronik yang mencakup proses pembelian, penjualan, transfer, atau pertukaran produk, layanan, atau informasi melalui jaringan komputer, termasuk internet. Model transaksi bisnis dalam e-commerce antara lain Business to Consumer (B2C), Business to Business (B2B), dan Consumer to Consumer (C2C). Segala macam kemudahan yang ditawarkan e-commerce inilah yang membuat konsumen lebih cenderung menelusuri kelengkapan informasi produk atau jasa melalui internet dan akan melakukan pembelian atau transaksi secara online. Konsumsi akan terus meningkat seiring dengan pertumbuhan populasi. Oleh karena itu, nilai transaksi e-commerce pun akan terus meningkat.

Tabel 1.1 Keinginan Konsumen Indonesia Membeli Produk atau Jasa Secara Online

\begin{tabular}{|c|c|c|}
\hline No. & Jenis Produk/Jasa & Intensi (\%) \\
\hline 1. & Tiket pesa wat & 55 \\
\hline 2. & Reservasihotel dan perjalanan & 46 \\
\hline 3. & Buku elektronik $($ e-books $)$ & 40 \\
\hline 4. & Pakaian, asesoris, sepatu & 37 \\
\hline 5. & Tiket a cara atau pertunjukan & 34 \\
\hline
\end{tabular}

The Nielsen Global Survey of E-Commerce melakukan studi mengenai intensi belanja online dari konsumen di seluruh dunia untuk membeli baik barang yang habis digunakan (consumable) maupun yang tidak habis digunakan (non-consumable) dalam pandangan e-commerce yang sedang bertumbuh. Pada Tabel 1.1, dapat dilihat bahwa sekitar setengah dari konsumen Indonesia berencana untuk membeli tiket pesawat secara online (55\%), di urutan kedua melakukan pemesanan hotel dan perjalanan (46\%), urutan ketiga yaitu konsumen berencana untuk membeli buku elektronik (e-books), lalu sisanya konsumen berencana untuk membeli pakaian, aksesoris, dan sepatu (37\%), dan lebih dari sepertiga konsumen merencanakan untuk membeli tiket acara atau pertunjukan (34\%) secara online. Dengan adanya fenomena ini, jasa travel perjalanan online termasuk salah satu bisnis yang menguntungkan bagi perusahaan.

Sektor perjalanan merupakan salah satu produk atau layanan yang banyak diakses melalui internet saat ini seiring dengan meningkatnya keperluan mobilitas antar daerah seperti wisata dan pekerjaan. Pelaku bisnis perjalanan perlu mengadopsi saluran distribusi elektronik untuk dapat bersaing secara efektif dalam lingkungan bisnis di era digital dengan perkembangan teknologi yang sangat pesat. Dua bagian dalam industri perjalanan yang telah diubah oleh perkembangan teknologi informasi adalah jasa pemesanan tiket pesawat dan akomodasi. Oleh karena itu, semakin banyak bermunculan perusahaan startup di di Indonesia yang bergerak di ranah pemesanan tiket pesawat dan akomodasi perhotelan.

Semakin meningkatnya jumlah pengguna internet serta tingginya intensi konsumen Indonesia untuk melakukan pemesanan kamar hotel dan perjalanan secara online, memberikan potensi bisnis kepada startup Agen Perjalanan Wisata (APW) berbasis online atau dikenal sebagai Online Travel Agent (OTA) untuk menjalankan bisnis usahanya di Indonesia. Tabel 1.2 menunjukkan hasil survei oleh dailysocial.id (2018) yang bertujuan mengukur pola konsumsi konsumen Indonesia terhadap layanan OTA. Survei dilakukan pada sebanyak 2013 responden melalui pada tahun 2018. Responden disampel secara proporsional terhadap populasi penduduk se-Indonesia. Hasil survei menunjukkan bahwa Antara 50\% hingga 70\% responden menggunakan Traveloka dan/atau Tiket.com untuk mereservasi tiket pesawat, tiket kereta, dan/atau ruang hotel. Sementara itu, Traveloka menjadi situs 
OTA terpopuler yang paling sering digunakan konsumen untuk mereservasi hotel dengan perolehan persentase sebesar $50,67 \%$.

Tabel 1.2 Hasil Survei Online Travel Agent (OTA) Terpopuler di Indonesia Tahun 2018

\begin{tabular}{|c|c|c|}
\hline No. & Online Travel Agent (OTA) & $\begin{array}{c}\text { Persentase Konsumen yang Pernah Melakukan } \\
\text { Reservasi Hotel (\%) }\end{array}$ \\
\hline 1. & Traveloka & 50,67 \\
\hline 2. & Tiket.com & 27,27 \\
\hline 3. & Airy & 20,20 \\
\hline 4. & Agoda & 19,63 \\
\hline 5. & PegiPegi & 19,47 \\
\hline 6. & JD.id & 10,64 \\
\hline 7. & Zen Rooms & 6,04 \\
\hline 8. & RedDoorz & 5,73 \\
\hline 9. & RajaKamar & 5,22 \\
\hline 10. & GoIndonesia & 4,70 \\
\hline 11. & Padiciti & 2,70 \\
\hline 12. & Lainnya & 5,32 \\
\hline
\end{tabular}

Seiring dengan banyaknya bisnis startup OTA di Indonesia terutama di sektor akomodasi perhotelan, dapat memberikan keuntungan kepada konsumen karena menciptakan banyak pilihan dalam melakukan pemesanan hotel secara online. Di sisi lain, hal tersebut menyebabkan semakin sempitnya pangsa pasar dan semakin meluasnya persaingan antar sektor jasa sejenis untuk menciptakan niat pelanggan dalam melakukan online booking hotel. Sebagai salah satu situs OTA terpopuler di Indonesia, Tiket.com memperoleh total transaksi sekitar 8 juta sepanjang tahun 2018 dan ini terjadi pada semua produk atau layanan yang tersedia. Pemesanan tiket pesawat mengalami pertumbuhan sekitar 300 persen dan sekitar 380 persen untuk pemesanan hotel (kompas.com, 2019).

PT. Global Tiket Network atau biasa yang dikenal sebagai Tiket.com merupakan salah satu perusahaan online travel agency yang menyediakan pelayanan reservasi hotel, tiket pesawat dan kereta api secara online, dimana usaha ini dibentuk pada tahun 2011 oleh 4 co-founder yaitu Natali Ardianto, Wenas Agustiawan, Dimas Surya dan Gaery Undarsa. Tiket.com merupakan salah satu startup lokal yang tidak tidak didanai oleh venture capital, Tiket.com hanya mengandalkan pendanaan awal dari angel investor yang jumlahnya kurang dari Rp 14 Milyar. Hingga saat ini, Tiket.com telah bekerja sama dengan berbagai maskapai penerbangan dan ribuan hotel dalam menjalani bisnisnya.

Kuta Selatan merupakan salah satu wilayah di Kabupaten Badung, Bali yang memiliki banyak objek wisata yang kerap dikunjungi para wisatawan baik domestik maupun mancanegara. Daya tarik di wilayah Kuta Selatan ialah panorama alam berupa pantai dan tebing sehingga mendapat perhatian para wisatawan seluruh dunia yang ingin melakukan aktivitas wisata bahari. Melihat potensi ini, pemerintah telah gencar melakukan perbaikan serta pengembangan di kawasan dan objek wisata tertentu seperti Jimbaran, Nusa Dua, Uluwatu, sehingga pengunjung mendapatkan akses yang layak dan menarik lebih banyak orang untuk mengunjungi wilayah ini.

Banyaknya wisatawan yang berlibur di wilayah Kuta Selatan juga berdampak pada berkembangnya penyedia akomodasi berupa hotel, villa, resort, homestay, guest house, dan sebagainya dalam menawarkan tempat menginap yang bervariasi kepada wisatawan. Oleh karena perkembangan teknologi dan perilaku konsumen, ratusan penyedia akomodasi perhotelan di wilayah Kuta Selatan telah menjalin kerja sama dengan berbagai online travel agent dalam menjual kamar dan layanan, salah satunya dengan Tiket.com. Segmentasi demografi konsumen online di wilayah Kuta Selatan yang beragam serta banyaknya jumlah penyedia akomodasi perhotelan di wilayah Kuta Selatan yang bekerja sama dengan online travel agent membuat peneliti tertarik untuk mengangkat penelitian dengan judul "Analisis Faktor-Faktor yang Mempengaruhi Konsumen Memilih Akomodasi pada Situs Tiket.com di Wilayah Kuta Selatan". Tujuan dari penelitian ini adalah untuk mengetahui faktor-faktor yang mempengaruhi konsumen memilih akomodasi pada situs Tiket.com di wilayah Kuta Selatan serta mengetahui faktor yang dominan atau paling banyak berkontribusi dalam mempengaruhi konsumen memilih akomodasi pada situs Tiket.com di wilayah Kuta Selatan. 


\section{METODE PENELITIAN}

Penelitian ini dilakukan di daerah Kuta Selatan, Badung sebagai salah satu daerah di Bali yang terdapat banyak objek wisata yang kerap dikunjungi para wisatawan baik domestik maupun mancanegara. Oleh karena itu, ratusan penyedia akomodasi perhotelan tersedia di lokasi ini. Metode pengumpulan data dalam penelitian ini menggunakan teknik kuesioner, dokumentasi, dan studi kepustakaan. Populasi dalam penelitian ini adalah konsumen yang pernah memilih akomodasi pada situs Tiket.com di wilayah Kuta Selatan. Sampel dalam penelitian ini berjumlah 100 orang melalui teknik penentuan sampel non probability sampling dengan menggunakan metode purposive sampling.Teknik analisis data yang digunakan adalah uji validitas, uji reliabilitas, dan analisis faktor . Terdapat 8 faktor yang mempengaruhi konsumen memilih akomodasi pada situs Tiket.com di wilayah Kuta Selatan yaitu menurut kemudahan (navigability/ease of use), informasi (content information), daya tarik visual web (aesthetics/visual attractiveness of site), layanan konsumen (customer services), pengalaman pengguna Tiket.com (experience), keamanan data pengguna situs Tiket.com (safety), motivasi pembelian (purchasing motivation), serta reputasi perusahaan/merek (corporate image). Faktor-faktor tersebut disajikan pada Tabel 2.1 berikut ini.

Tabel 2.1 Faktor-Faktor yang Mempengaruhi Konsumen Memilih Akomodasi pada Situs Tiket.com

\begin{tabular}{|c|c|c|}
\hline No. & Faktor $(\mathbf{X})$ & Variabel \\
\hline 1. & $\begin{array}{l}\text { Kemudahan } \\
\text { (Navigability/Ease of Use) }\end{array}$ & $\begin{array}{l}\text { 1. Kemudahan pada saat mencari situs web(X1) } \\
\text { 2. Waktu yang dihabiskan untuk mengakses web }(\mathrm{X} 2) \\
\text { 3. Nama domain perusahaan yang digunakan }(\mathrm{X} 3) \\
\text { 4. Kemudahan pada saat melakukan pemesanan }(\mathrm{X} 4)\end{array}$ \\
\hline 2. & $\begin{array}{l}\text { Informasi(Content } \\
\text { Information) }\end{array}$ & $\begin{array}{l}\text { 1. Informasi yang lengkap (X5) } \\
\text { 2. Informasi y ang akurat (X6) } \\
\text { 3. Informasi yang disajikan menarik (X7) }\end{array}$ \\
\hline 3. & $\begin{array}{l}\text { Daya Tarik Visual Web } \\
\text { (Aesthetics/Visual } \\
\text { Attractiveness Of Site) }\end{array}$ & $\begin{array}{l}\text { 1. Tampilan warna web yang menarik dan tidak } \\
\text { mengganggu kecepatan loading }(\mathrm{X} 8) \\
\text { 2. Jenis huruf mudah dimengerti }(\mathrm{X} 9) \\
\text { 3. Pema paran informasi yang tepat (X10) }\end{array}$ \\
\hline 4. & $\begin{array}{l}\text { Layanan Konsumen } \\
\text { (Customer Services) }\end{array}$ & $\begin{array}{l}\text { 1. Kemudahan pengaduan keluhan (X11) } \\
\text { 2. Kecepatan waktu pelayanan (X12) } \\
\text { 3. Ketepatan waktu pelayanan (X13) }\end{array}$ \\
\hline 5. & Pengalaman(Experience) & $\begin{array}{l}\text { 1. Ketersediaan dan aksesibilitas (X14) } \\
\text { 2. Harga yang kompetitif (X15) } \\
\text { 3. Pengalaman secara keseluruhan (X16) }\end{array}$ \\
\hline 6. & Keamanan (Safety) & $\begin{array}{l}\text { 1. Kea manan data pribadi }(\mathrm{X} 17) \\
\text { 2. Kea manan saat melakukan pembayaran }(\mathrm{X} 18)\end{array}$ \\
\hline 7. & $\begin{array}{l}\text { MotivasiPembelian } \\
\text { (Purchasing Motivation), }\end{array}$ & $\begin{array}{l}\text { 1. Dorongan keluarga (X19) } \\
\text { 2. Situa si konsumen }(\mathrm{X} 20) \\
\text { 3. Personal image }(\mathrm{X} 21)\end{array}$ \\
\hline 8. & $\begin{array}{l}\text { ReputasiPerusahaan/Merek } \\
\text { (CorporateImage) }\end{array}$ & $\begin{array}{l}\text { 1. Nama baik (X22) } \\
\text { 2. Reputasi dibanding pesaing (X23) } \\
\text { 3. Dikenalluas (X24) } \\
\text { 4. Kemudahan diingat (X15) }\end{array}$ \\
\hline
\end{tabular}

Sumber: TRust dan Kannan(2012), Korpert dan Elliss (2011)

\section{HASIL DAN PEMBAHASAN}

\subsection{Karakteristik Responden}

Jumlah responden pada penelitian ini adalah sebanyak 100 orang yang diperoleh dari penyebaran kuesioner menggunakan google form. Responden merupakan para pengguna yang sudah pernah melakukan pembelian atau reservasi hotel di daerah Kuta Selatan melalui Tiket.com. Karakteristik responden dalam penelitian ini ditinjau dari beberapa variabel demografi yang digambarkan melalui variabel jenis kelamin, umur, dan pekerjaan yang ditunjukkan pada Tabel 3.1 
Tabel 3.1 Karakteristik Demografi Responden

\begin{tabular}{|c|c|c|c|c|}
\hline $\begin{array}{l}\mathbf{N} \\
\text { o. }\end{array}$ & Kriteria & Klasifikasi & $\begin{array}{l}\text { Jumlah } \\
\text { (Orang) }\end{array}$ & $\begin{array}{c}\text { Persenta se } \\
(\%)\end{array}$ \\
\hline \multirow[t]{2}{*}{1.} & \multirow[t]{2}{*}{ Jenis Kelamin } & Laki-Laki & 43 & 43 \\
\hline & & Perempuan & 57 & 57 \\
\hline & & Jumlah & 100 & 100 \\
\hline \multirow[t]{5}{*}{2.} & \multirow[t]{5}{*}{ Umur } & $17-23$ tahun & 31 & 31 \\
\hline & & $>23-30$ tahun & 36 & 36 \\
\hline & & $>30-37$ tahun & 22 & 22 \\
\hline & & $>37-44$ tahun & 8 & 8 \\
\hline & & $>44$ tahun & 3 & 3 \\
\hline & & Jumlah & 100 & 100 \\
\hline \multirow[t]{5}{*}{3.} & \multirow[t]{5}{*}{ Pekerjaan } & Pelajar/Mahasiswa & 19 & 19 \\
\hline & & PegawaiNegeriSipil & 10 & 10 \\
\hline & & PegawaiSwa sta & 44 & 44 \\
\hline & & Wiraswasta & 22 & 22 \\
\hline & & $\begin{array}{l}\text { Lainnya } \\
\end{array}$ & 5 & 5 \\
\hline & & Jumlah & 100 & 100 \\
\hline
\end{tabular}

Berdasarkan uraian Tabel 4.1, dapat dilihat bahwa responden dengan jenis kelamin perempuan lebih banyak dibandingkan laki-laki. Responden berjenis kelamin perempuan berjumlah 57 orang atau sebesar 57\% dari total sampel secara keseluruhan, sedangkan responden laki-laki sebanyak 43 orang atau sebesar 43\%. Hasil ini dapat berarti bahwa mayoritas pengguna Tiket.com yang melakukan pembelian atau reservasi hotel di daerah Kuta Selatan didominasi oleh perempuan.

Ditinjau dari kriteria umur, responden dengan rentang umur lebih dari 23 sampai 30 tahun mendominasi sebaran kuesioner ini yaitu sebesar 36\% yang menunjukkan bahwa mayoritas responden berada pada jenjang usia produktif atau sedang bekerja maupun sedang menempuh pendidikan tinggi sehingga membutuhkan reservasi hotel untuk akomodasi berlibur atau perjalanan bisnis. Sementara itu, responden dengan rentang umur 17 sampai 23 tahun adalah sebesar 31\%, rentang umur lebih dari 30 sampai 37 tahun sebesar 22\%, rentang umur lebih dari 37 sampai 44 tahun sebesar $8 \%$, serta responden yang umurnya lebih dari 44 tahun sebesar $3 \%$.

Responden yang bekerja sebagai pegawai swasta mendominasi sebaran kuesioner dengan persentase sebesar $44 \%$. Sebesar $22 \%$ responden adalah wiraswasta, sebesar $19 \%$ responden merupakan pelajar atau mahasiswa, sebesar $10 \%$ responden memiliki pekerjaan sebagai Pegawai Negeri Sipil, serta lainnya sebesar 5\%.

\subsection{Hasil Uji Validitas}

Pengujian validitas dilakukan dengan menghitung nilai Korelasi Pearson untuk mengetahui hubungan antara variabel data yang berskala interval (Yamin dan Kurniawan, 2011). Suatu instrumen dikatakan valid apabila Pearson Correlation terhadap skor total di atas 0,30 (Sugiyono, 2017). Hasil uji validitas instrumen penelitian disajikan pada Tabel 4.3 yang menunjukkan bahwa seluruh indikator pernyataan dalam kuesioner memiliki nilai Pearson Correlation yang lebih besar dari angka 0,30 sehingga seluruh indikator tersebut telah memenuhi syarat validitas data.

\section{Tabel 3.2 Hasil Uji Validitas}

\begin{tabular}{|c|c|c|c|}
\hline Faktor & Indikator & $\begin{array}{c}\text { Nilai } \\
\text { Pearson Correlation }\end{array}$ & Keterangan \\
\hline \multirow{3}{*}{$\begin{array}{c}\text { Kemudahan } \\
\text { (Navigability/Ease ofUse) }\end{array}$} & $\mathrm{X} 1$ & 0,667 & Valid \\
\cline { 2 - 4 } & $\mathrm{X} 2$ & 0,566 & Valid \\
\cline { 2 - 4 } & $\mathrm{X} 3$ & 0,611 & Valid \\
\cline { 2 - 4 } & $\mathrm{X} 4$ & 0,635 & Valid \\
\hline \multirow{2}{*}{$\begin{array}{c}\text { Informasi(Content } \\
\text { Information) }\end{array}$} & $\mathrm{X} 5$ & 0,561 & Valid \\
\cline { 2 - 4 } & $\mathrm{X} 6$ & 0,630 & Valid \\
\cline { 2 - 4 } & $\mathrm{X} 7$ & 0,563 & Valid \\
\hline
\end{tabular}




\begin{tabular}{|c|c|c|c|}
\hline \multirow{3}{*}{$\begin{array}{c}\text { Daya Tarik Visual Web } \\
\text { (Aesthetics/Visual } \\
\text { Attractiveness Of Site) }\end{array}$} & X8 & 0,667 & Valid \\
\hline & $\mathrm{X} 9$ & 0,631 & Valid \\
\hline & $\mathrm{X} 10$ & 0,656 & Valid \\
\hline \multirow{3}{*}{$\begin{array}{l}\text { Layanan Konsumen } \\
\text { (Customer Services) }\end{array}$} & $\mathrm{X} 11$ & 0,701 & Valid \\
\hline & $\mathrm{X} 12$ & 0,623 & Valid \\
\hline & $\mathrm{X} 13$ & 0,690 & Valid \\
\hline \multirow[t]{3}{*}{ Penga laman(Experience) } & $\mathrm{X} 14$ & 0,712 & Valid \\
\hline & $\mathrm{X} 15$ & 0,522 & Valid \\
\hline & $\mathrm{X} 16$ & 0,581 & Valid \\
\hline \multirow[t]{2}{*}{ Keamanan (Safety) } & $\mathrm{X} 17$ & 0,730 & Valid \\
\hline & $\mathrm{X} 18$ & 0,641 & Valid \\
\hline \multirow{3}{*}{$\begin{array}{c}\text { MotivasiPembelian } \\
\text { (Purchasing Motivation) }\end{array}$} & $\mathrm{X} 19$ & 0,696 & Valid \\
\hline & $\mathrm{X} 20$ & 0,782 & Valid \\
\hline & $\mathrm{X} 21$ & 0,812 & Valid \\
\hline \multirow{4}{*}{$\begin{array}{c}\text { Reputasi Perusahaan/Merek } \\
\text { (CorporateImage) }\end{array}$} & $\mathrm{X} 22$ & 0,817 & Valid \\
\hline & $\mathrm{X} 23$ & 0,768 & Valid \\
\hline & $\mathrm{X} 24$ & 0,768 & Valid \\
\hline & $\mathrm{X} 25$ & 0,786 & Valid \\
\hline
\end{tabular}

\subsection{Hasil Uji Reliabilitas}

Uji reliabilitas bertujuan untuk mengetahui sejauh mana alat ukur dapat dipercaya atau dapat diandalkan. Pengujian reliabilitas dilakukan terhadap instrumen dengan koefisien cronbach's alpha. Apabila nilai cronbach's alpha lebih besar dari 0,60 maka instrumen yang digunakan reliabel. Hasil pengujian pada Tabel 4.4 menunjukan bahwa nilai korelasi masing-masing variabel dari yang diuji memiliki nilai cronbanch's alpha yang lebih besar dari 0,60. Dengan demikian dapat disimpulkan bahwa semua instrumen atau variabel yang digunakan dalam penelitian ini dapat dikatakan reliabel. Hasil uji reliabilitas disajikan pada Tabel 4.4 berikut ini.

Tabel 3.3

Hasil Uji Reliabilita s

\begin{tabular}{|c|c|c|c|}
\hline Faktor & Indikator & $\begin{array}{c}\text { Nilai } \\
\text { Cronbanch's Alpha }\end{array}$ & Keterangan \\
\hline \multirow{4}{*}{$\begin{array}{c}\text { Kemudahan } \\
\text { (Navigability/Ease ofUse) }\end{array}$} & $\mathrm{X1}$ & 0,947 & Valid \\
\hline & $\mathrm{X} 2$ & 0,949 & Valid \\
\hline & $\mathrm{X} 3$ & 0,948 & Valid \\
\hline & $\mathrm{X} 4$ & 0,948 & Valid \\
\hline \multirow{3}{*}{$\begin{array}{l}\text { Informasi (Content } \\
\text { Information) }\end{array}$} & $\mathrm{X} 5$ & 0,949 & Valid \\
\hline & $\mathrm{X} 6$ & 0,949 & Valid \\
\hline & $\mathrm{X} 7$ & 0,948 & Valid \\
\hline \multirow{3}{*}{$\begin{array}{c}\text { Daya Tarik Visual Web } \\
\text { (Aesthetic s/Visual } \\
\text { Attractiveness OfSite) }\end{array}$} & $\mathrm{X} 8$ & 0,947 & Valid \\
\hline & $\mathrm{X} 9$ & 0,948 & Valid \\
\hline & $\mathrm{X} 10$ & 0,947 & Valid \\
\hline \multirow{3}{*}{$\begin{array}{l}\text { Layanan Konsumen } \\
\text { (Customer Services) }\end{array}$} & $\mathrm{X} 11$ & 0,947 & Valid \\
\hline & $\mathrm{X} 12$ & 0,948 & Valid \\
\hline & $\mathrm{X} 13$ & 0,947 & Valid \\
\hline \multirow{3}{*}{ Penga laman(Experience) } & $\mathrm{X} 14$ & 0,947 & Valid \\
\hline & $\mathrm{X} 15$ & 0,949 & Valid \\
\hline & $\mathrm{X} 16$ & 0,948 & Valid \\
\hline \multirow[t]{2}{*}{ Keamanan (Safety) } & $\mathrm{X} 17$ & 0,947 & Valid \\
\hline & $\mathrm{X} 18$ & 0,948 & Valid \\
\hline \multirow{3}{*}{$\begin{array}{c}\text { Motivasi Pembelian } \\
\text { (PurchasingMotivation) }\end{array}$} & X19 & 0,947 & Valid \\
\hline & $\mathrm{X} 20$ & 0,946 & Valid \\
\hline & X21 & 0,945 & Valid \\
\hline \multirow{4}{*}{$\begin{array}{c}\text { Reputasi Perusaha an/Merek } \\
\text { (Corporate Image) }\end{array}$} & X22 & 0,945 & Valid \\
\hline & $\mathrm{X} 23$ & 0,946 & Valid \\
\hline & X24 & 0,946 & Valid \\
\hline & X25 & 0,946 & Valid \\
\hline
\end{tabular}




\subsection{Hasil Analisis Faktor}

Analisis data yang digunakan dalam penelitian ini adalah analisis faktor. Analisis faktor merupakan independent technique yaitu teknik analisis multivariate untuk melacak (Confirmatory) hubungan dari seluruh independent variable (butir item) dengan variabel lainnya. Analisis Faktor konfirmatori digunakan untuk mengkonfirmasi faktor-faktor yang dibentuk untuk mendifinisikan sebuah konsep atau konstruk penelitian (Ferdinan, 2014). Setelah melewati serangkaian tahapan analisis faktor, maka interpretasi faktor adalah sebagai berikut.

\section{a. Faktor 1 (Kemudahan dan Sistem Informasi Situs)}

Kemudahan dan sistem informasi situs termasuk salah satu faktor yang mempengaruhi konsumen untuk melakukan pembelian atau reservasi hotel melalui Tiket.com dengan nilai eigen value sebesar 11,494. Terdapat 13 variabel yang tercakup pada faktor ini, yaitu:

1) Kemudahan pada saat mencari situs web (X1)

2) Waktu yang dihabiskan untuk mengakses web (X2)

3) Nama domain perusahaan yang digunakan (X3)

4) Kemudahan pada saat melakukan pemesanan (X4)

5) Informasi yang lengkap (X5)

6) Informasi yang akurat (X6)

7) Informasi yang disajikan menarik (X7)

8) Pemaparan informasi yang tepat (X10)

9) Ketersediaan dan aksesibilitas (X14)

10) Harga yang kompetitif (X15)

11) Pengalaman secara keseluruhan (X16)

12) Keamanan data pribadi (X17)

13) Keamanan saat melakukan pembayaran (X18)

Faktor ini menjelaskan keragaman dari variabel sebesar 45,978\%. Dari lima faktor yang ditemukan, faktor 1 mempunyai nilai varian yang paling besar dibanding faktor-faktor lainnya. Jika dilihat dari loadings factor, maka variabel informasi yang lengkap (X5) merupakan variabel yang mewakili faktor 1 dengan nilai loadings factor sebesar 0,782 , kemudian variabel nama domain perusahaan yang digunakan (X3) dengan nilai loadings factor sebesar 0,767, variabel keamanan saat melakukan pembayaran (X18) dengan nilai loadings factor sebesar 0,744, variabel kemudahan pada saat melakukan pemesanan (X4), dengan nilai loadings factor sebesar 0,690, variabel harga yang kompetitif (X15) dengan nilai loadings factor sebesar 0,672, variabel kemudahan pada saat mencari situs web (X1) dengan nilai loadings factor sebesar 0,647, variabel informasi yang akurat (X6) dengan nilai loadings factor sebesar 0,647, variabel waktu yang dihabiskan untuk mengakses web (X2) dengan nilai loadings factor sebesar 0,623, variabel ketersediaan dan aksesibilitas (X14) dengan nilai loadings factor sebesar 0,618, variabel keamanan data pribadi (X17) dengan nilai loadings factor sebesar 0,615, serta variabel pengalaman secara keseluruhan (X16) dengan nilai loadings factor sebesar 0,563 .

\section{b. Faktor 2 (Daya Tarik Visual Situs)}

Daya tarik visual situs termasuk salah satu faktor yang mempengaruhi konsumen untuk melakukan pembelian atau reservasi hotel melalui Tiket.com dengan nilai eigen value sebesar 1,799. Terdapat 2 variabel yang tercakup pada faktor ini, yaitu:

1) Tampilan warna web yang menarik dan tidak mengganggu kecepatan loading (X8)

2) Jenis huruf mudah dimengerti (X9)

Faktor ini menjelaskan keragaman dari variabel sebesar 7,196\%. Jika dilihat dari loadings factor, variabel tampilan warna web yang menarik dan tidak mengganggu kecepatan loading (X8) merupakan variabel yang mewakili faktor 2 dengan nilai loadings factor sebesar 0,763 serta variabel jenis huruf mudah dimengerti dengan nilai loadings factor sebesar 0,717.

\section{c. Faktor 3 (Pelayanan Konsumen)}

Pelayanan konsumen termasuk salah satu faktor yang mempengaruhi konsumen untuk melakukan pembelian atau reservasi hotel melalui Tiket.com dengan nilai eigen value sebesar 1,529. Terdapat 3 variabel yang tercakup pada faktor ini, yaitu:

1. Kemudahan pengaduan keluhan (X11) 
2. Kecepatan waktu pelayanan (X12)

3. Ketepatan waktu pelayanan (X13)

Faktor ini menjelaskan keragaman dari variabel sebesar 6,117\%. Jika dilihat dari loadings factor, kecepatan waktu pelayanan (X12) merupakan variabel yang mewakili faktor 3 dengan nilai loading $s$ factor sebesar 0,657, variabel kemudahan pengaduan keluhan (X11) dengan nilai loadings factor sebesar 0,653, serta variabel ketepatan waktu pelayanan (X13) dengan nilai loadings factor sebesar 0,570 .

\section{d. Faktor 4 (Citra Perusahaan)}

Citra perusahaan termasuk salah satu faktor yang mempengaruhi konsumen untuk melakukan pembelian atau reservasi hotel melalui Tiket.com dengan nilai eigen value sebesar 1,133. Terdapat 3 variabel yang tercakup pada faktor ini, yaitu:

1) Nama baik (X22)

2) Reputasi dibanding pesaing (X23)

3) Dikenal luas (X24)

Faktor ini menjelaskan keragaman dari variabel sebesar 4,530\%. Jika dilihat dari loadings factor, nama baik (X22) merupakan variabel yang mewakili faktor 4 dengan nilai loadings factor sebesar 0,616, variabel dikenal luas (X24) dengan nilai loadings factor sebesar 0,602, serta variabel reputasi dibanding pesaing (X23) dengan nilai loadings factor sebesar 0,526.

\section{e. Faktor 5 (Motivasi Pembelian)}

Motivasi pembelian termasuk salah satu faktor yang mempengaruhi konsumen untuk melakukan pembelian atau reservasi hotel melalui Tiket.com dengan nilai eigen value sebesar 1,014. Terdapat 4 variabel yang tercakup pada faktor ini, yaitu:

1) Dorongan keluarga (X19)

2) Situasi konsumen (X20)

3) Personal image (X21)

4) Kemudahan diingat (X25)

Faktor ini menjelaskan keragaman dari variabel sebesar 4,057\%. Jika dilihat dari loadings factor, kemudahan diingat (X25) merupakan variabel yang mewakili faktor 5 dengan nilai loadings factor sebesar 0,778, variabel dorongan keluarga (X19) dengan nilai loadings factor sebesar 0,700, variabel personal image (X21) dengan nilai loadings factor sebesar 0,692, serta variabel situasi konsumen (X20) dengan nilai loadings factor sebesar 0,607.

Penelitian yang bertujuan untuk mengetahui faktor-faktor yang mempengaruhi konsumen memilih akomodasi pada situs Tiket.com di wilayah Kuta Selatan ini mendapatkan hasil analisis data sebagai berikut: terdapat 5 faktor yang terbentuk dari 25 variabel awal yang telah ditetapkan. Faktor yang terbentuk adalah: kemudahan dan sistem informasi situs $(45,978 \%)$, daya tarik visual situs $(7,196 \%)$, pelayanan konsumen $(6,117 \%)$, citra perusahaan $(4,530 \%)$, serta motivasi pembelian $(4,057 \%)$. Adapun faktor yang paling banyak berkontribusi dalam mempengaruhi konsumen memilih akomodasi pada situs Tiket.com di wilayah Kuta Selatan adalah faktor terbentuk yang memiliki loadings factor tertinggi dari keseluruhan faktor yang terbentuk. Berdasarkan hasil penelitian, maka yang menjadi faktor utama adalah faktor 1 yaitu kemudahan dan sistem informasi situs yang terdiri dari 13 variabel yakni: (1) kemudahan pada saat mencari situs web, (2) waktu yang dihabiskan untuk mengakses web, (3) nama domain perusahaan yang digunakan, (4) kemudahan pada saat melakukan pemesanan, (5) informasi yang lengkap, (6) informasi yang akurat, (7) informasi yang disajikan menarik, (8) pemaparan informasi yang tepat, (9) ketersediaan dan aksesibilitas, (10) harga yang kompetitif, (11) pengalaman secara keseluruhan, (12) keamanan data pribadi, serta (13) keamanan saat melakukan pembayaran.

Faktor kemudahan dan sistem informasi situs mendominasi faktor-faktor lainnya dengan percent of variance sebesar 45,978\% dan nilai eigen value sebesar 11,494. Hasil ini dapat berarti bahwa konsumen memiliki keinginan atau terdorong untuk memilih akomodasi pada situs Tiket.com di wilayah Kuta Selatan dikarenakan mudahnya mengakses situs Tiket.com saat akan melakukan reservasi mulai dari proses pencarian informasi, pemesanan hotel, melakukan pembayaran, hingga selesai melakukan pemesanan. Selain itu, sistem informasi yang baik akan memudahkan pengguna pada saat ingin melakukan reservasi melalui situs tanpa adanya gangguan yang berdampak pada proses pemesanan. 


\section{K ESIMPULAN}

Berdasarkan hasil pembahasan, dapat ditarik kesimpulan yaitu faktor-faktor yang mempengaruhi konsumen memilih akomodasi pada situs Tiket.com di wilayah Kuta Selatan terdiri dari 5 faktor di antaranya: faktor pertama yaitu kemudahan dan sistem informasi situs yang terdiri dari 13 variabel dengan nilai percent of variance sebesar $45,978 \%$ dan eigen value sebesar 11,494, faktor kedua yaitu daya tarik visual situs yang terdiri dari 2 variabel dengan nilai percent of variance sebesar 7,196\% dan eigen value sebesar 1,799, faktor ketiga yaitu pelayanan konsumen yang terdiri dari 3 variabel dengan nilai percent of variance sebesar $6,117 \%$ dan eigen value sebesar 1,529, faktor keempat yaitu citra perusahaan yang terdiri dari 3 variabel dengan nilai percent of variance sebesar $4,530 \%$ dan eigen value sebesar 1,133, faktor kelima yaitu motivasi pembelian yang terdiri dari 4 variabel dengan nilai percent of variance sebesar $4,057 \%$ dan eigen value sebesar 1,014. Faktor yang mendominasi dalam mempengaruhi konsumen memilih akomodasi pada situs Tiket.com di wilayah Kuta Selatan adalah faktor pertama yaitu kemudahan dan sistem informasi situs.

\section{DAFTAR PUSTAKA}

Daily Social Indonesia. 2018. Hasil Survei Online Travel Agent (OTA) Terpopuler di Indonesia

Tahun 2018. Diakses dari https://www.dailysocial.id.

Ferdinand, Augusty. 2004. Structural Equation Modeling dalam Penelitian Manajemen. Semarang: BP Universitas Diponegoro

Kompas. 2019. Transaksi Tiket.com Tumbuh Hampir 3 Kali Lipat Sepanjang 2018. Diakses dari

https://ekonomi.kompas.com.

Korpert, Steffano dan Juanitta Ellis. 2011. The E-Commerce Book-Building The E-Empire. Florida: Academic Press.

Muliana, Erni, I Made Kusuma Negara dan Luh Gede Leli Kusuma Dewi. 2016. Analisis Faktor-

Faktor yang Mendorong Wisatawan Melakukan Keputusan Pembelian Tiket Pesawat Melalui

Mobile Booking pada Situs Traveloka.com. Jurnal IPTA, Vol.4. No.1, pp. 79-85.

Rust T, Roland dan P.K Kannan. 2002. A Service New Direction in Theory and Practice. United

States of America.

Sugiyono, 2014. Metode Penelitian Manajemen. Bandung: Penerbit Alfabeta.

Sugiyono, 2017. Metode Penelitian Kuantitatif, Kualitatif dan R\&D. Bandung: PT Alfabet. Sutopo, Eng Yeri dan Achmad Slamet. 2017. Statistik Inferensial. Yogyakarta: ANDI.

The Nielsen Global Survey of E-Commerce. 2016. Keinginan Konsumen Indonesia Membeli Produk atau Jasa Secara Online. Diakses dari www.nielsen.com/id.

Utama, Made Suyana. 2016. Aplikasi Analisis Kuantitatif. Denpasar: CV. Sastra Utama.

Utama, Rai I.G.Bagus dan Ni Made Mahadewi. 2012. Metode Penelitian Pariwisata dan Perhotelan.

Yogyakarta: CV Andi Offset. 